\title{
Impact of Shimla Agreement on the Application of UN Resolutions on Jammu and Kashmir: A Critical Analysis under International Law
}

\section{Adnan Rahman}

Lecturer

Department of Law

Universityof AJK, Muzaffarabad

mir.adnan.rahman@gmail.com

\section{Sania Muneer}

Assistantprofessor

Schoolof Integrated Social Sciences

Universityof Lahore

sania.muneer@siss.uol.edu.pk

\section{Muhammad Mumtaz Ali Khan}

Director (Research and Development)

Punjab Higher Education Commission, Lahore

mumtaz.ali@punjabhec.gov.pk

\section{Abstract}

The purpose of this paper is to explore and analyze the impact of the Shimla Agreement on the application of the United Nations' resolution on Jammu and Kashmir with special reference to the International law. The conflict of Jammu and Kashmir has been a longstanding conflict for right to self-determination for people of Jammu and Kashmir. There are almost twenty resolutions of the UNSC and UNCIP on Jammu and Kashmir and the issue is still pending in the United Nations Security Council. However, there has been a debate on the impact of the Shimla agreement on the applicability and validity of the resolutions of the United Nations in post 1972 scenario. This paper will critically analyze and objectively review the various legal dimensions of the Shimla Agreement in juxtaposition with the leading principles of International law as well as decisions of the ICJ on similar matters. Moreover, this paper will also analyze the nature, scope and applicability of the resolutions of the UNSC and UNCIP in the light of the International law. The findings of this research work are based upon the critical review of the existing literature on the Shimla Agreementand its impact on the UN Resolutions. This study

(C) 2021 The Authors, Published by The Women University Multan. This is an Open Access Article under the Creative Common Attribution Non-Commercial 4.0
Date of Acceptance: 01 December 2021 Available Online: 26 December 2021 
will suggest the effective analysis and will address all the questions pertaining to the nature, scope and legal impact of the Shimla Agreement on the nature and scope of applicability of UN Resolutions on Jammu and Kashmir. This study can be very useful and relevant in future to analyze the nature of the Shimla agreement and the binding nature and applicability of the resolutions of the United Nations on Jammu and Kashmir.

Keywords: Shimla agreement, Resolutions of United Nations, conflict of Jammu and Kashmir, International Law and International court of Justice

\section{Introduction}

Both India and Pakistan have entered into many bilateral agreements to develop mutual understandings and building the trusts to settle all the differences including the longstanding conflict of Jammu and Kashmir. The Shimla Agreement is also one of the bilateral agreements between India and Pakistan. ${ }^{1}$ This Agreement was entered into between both the neighboring countries in 1972 and it had multifarious legal, political and diplomatic effects in post Shimla Agreement's scenario. This Agreement was signed at a time when Pakistan was facing severe challenges at military, political and economic fronts. The incident of Dakha fall in 1971, arrest of thousands of Prisoners of Wars (POWs) by India in East Pakistan (which became Bangladesh in 1971) and division of Pakistan were few circumstances under which th is Agreement was negotiated by the foreign Minister of Pakistan and then signed by President of Pakistan at Shimla, capital of Hamachal Pradesh, India. ${ }^{2}$

There is a debate in the intellectual circles about the impact of the Shimla Agreement on the resolutions of the United Nations on Jammu and Kashmir. Few people, mostly from India, think and claim that Shimla Agreement made it mandatory for India and Pakistan to resolve all the bilateral issues peacefully through bilateral negotiations without any intervention of the third parties or states or even United Nations. On the other hand, the other group of scholars, mostly from Pakistan, is of the opinion that Shimla Agreement has no direct impact on the resolutions of the United Nations Security Council (UNSC) and United Nations Commission on India and Pakistan (UNCIP) and all the resolutions are still valid, 
applicable and important in resolving the conflict of Jammu and Kashmir $^{3}$.

This debate is very complex and corresponding arguments of both the parties are also very confusing and sometimes without the real reflection of the International law on this very important issue. There are well recognized and enforceable principles of the International law which deals with the correlation between the bilateral treaty like Shimla Agreement and the resolutions of the United Nations Security Council (UNSC). ${ }^{4}$ There are also many decisions of the International court of Justice (ICJ) on this very important issue. Moreover, the relevant provisions of the Charter of the United Nations is also an important legal document to guide the states and the individuals about the different legal issues and challenges and the debate of the relationship between Shimla agreement and the resolutions of the United Nations can also be analyzed and reviewed with the help of these well recognized and leading principles and provisions of the International law.

This is very necessary to critically analyze and objectively review the nature, scope and application of the Shimla agreement in juxtaposition with the nature, scope and application of the resolutions of the United Nations in order to compare both these legal authorities and to explore their legal relationships and legal impacts on each other. This critical analysis and comparative studies will provide an objective and in-depth understanding about the impact of the Shimla Agreement on the applicability and validity of the resolutions of the UNSC and UNCIP.

\section{Shimla Agreement: Nature and scope}

The Shimla Agreement is a bilateral treaty between India and Pakistan which was negotiated between the foreign Ministers of both the neighboring states and then signed by the President of Pakistan and Prime Minister of India. ${ }^{5}$ Later on, the parliaments of both the states ratified the Shimla Agreement as per prevailing legal systems of both the states and since 1972, the Shimla Agreement is a valid, enforceable and applicable bilateral treaty between India and Pakistan. This agreement has not been unilaterally withdrawn by any state so far and both the states respect and principally follow the 
provisions of the Shimla Agreement under the leading principles and guidelines of the International Law.

The primary motive and intentions behind this agreement was to find out a permanent solution to prevent any conflict and confrontations between India and Pakistan in future through a mutually negotiated and agreed bilateral treaty. This agreement was entered into between both the states after a protracted armed conflict between India and Pakistan which resulted into the division of Pakistan and emergence of a new state named as "Bangladesh". Moreover, Pakistan was also under severe diplomatic and political pressure due to the presence of almost ninety six thousands Prisoners of Wars (POWs) in the enemy state of India. So as a result of this agreement both India and Pakistan agreed to resolve their mutual issues bilaterally and peacefully through a mutual framework of negotiations and dialogue processes and India also released all the POWs and sent them back to Pakistan. ${ }^{6}$

The careful analysis and perusal of the text of the Shimla Agreement, 1972 reveals the following salient points of this historical agreement ${ }^{7}$ :

a) The first paragraph of the agreement highlight the intentions and objectives of this agreement. According to this paragraph, the basic objective of this agreement is to prevent bilateral conflicts and confrontations in future to promote peace and harmony in this region of South Asia. It also aims to foster welfare of the people of South Asia through lasting and durable peace.

b) The first clause of the Shimla Agreement, 1972, both the states agreed that the relationships between both the states will be governed and regulated by the purposes and principles of the charter of the United Nations. There are many significant principles of the Charter of the United Nations and the primary purposes of the Charter of UN was to bring peace and prosperity in the world and to advance and foster the welfare and wellbeing of the people across the world through negotiations and prevention of the conflicts.

c) In second clause of the agreement, both the states resolved to settle their differences peacefully through bilateral 
negotiations or through some other peaceful process as agreed and settled between India and Pakistan. This clause is very important as it highlights the significance of the peaceful settlement of the disputes between India and Pakistan through peaceful negotiations.

d) The third clause of the agreement recognizes four very important and cordial principles to be followed by both the states. These principles are peaceful coexistence, respect of each other territorial integrity, sovereignty and noninterference in each other internal affairs. These four principles can be regarded as the hallmark and central concept of the agreement. It was also agreed by both the states that these four principles are the pre requisite for reconciliations, good neighborliness and durable peace if followed and adhered by both the states with good faith and positive intentions. It was also decided by both the states that both will follow these four principles with the attitude and state of mind that both are acting on the basis of equality and mutual benefit. This clause is the gist of the whole agreement and provide a very viable and effective theoretical framework with values and frameworks to attain lasting peace and development in the south Asia. ${ }^{8}$

e) The fourth clause of this agreement is very significant and has great historical relevancy with the role of India in unlawful military interference in East Pakistan during an insurgency of Bengalis against Pakistan. This clause stressed on four important principles to be strictly adhered by both the states so that such kind of ill will and maliciously motivated military actions can be prevented by both the states against each other. This clause speaks about the respect of national unity, territorial integrity, political independence and sovereign equality. These four principles are also key to promote lasting peace and peaceful coexistence in this region which has two nuclear states and a longstanding conflict of Jammu and Kashmir which has become a nuclear flash point due to three nuclear states: India, China and Pakistan.

f) The fifth clause of the agreement also highlight the significance of the territorial integrity and political 
independence and refrain both India and Pakistan to give any threat or use any force against the territorial integrity and political independence of each other under the provisions and principles of the charter of the United Nations. ${ }^{9}$

g) In the next paragraph, some Confidence building measures (CBMs) were also agreed between both India and Pakistan to promote friendly relationships and to prevent the hostile propaganda against each other in an effective and positive way.

h) In the last clause of this agreement, both the states mutually agreed on some practical measures to be implemented immediately in order to move towards lasting peace and harmony. One of the main practical steps was the conversion of ceasefire line into Line of Control and recognition of this Line of Control by both the states with commitments that no side will threat or use of force in violation of this line ${ }^{10}$. Moreover, both the states also agreed to not unilaterally alter the Line of Control to promote peace and stability across Line of Control as well. Besides, it was also decided that the armed forces of both the states will be withdrawn to their sides of the international border so that situation of peace and harmony can be restored without any further violence.

The Shimla agreement was the most effective agreement between both the states which was also implemented between both the states as per the spirit and timeline being stipulated by the agreement. The measures which were implemented or actions which were taken immediately or within stipulated time after this agreement were as under:

a) Conversion of Ceasefire Line (CFL) into Line of Control (LoC). As United Nations Military Observers Group in India and Pakistan (UNMOGIP) was mandated by United Nations in pursuance of the resolutions of the UNSC and UNCIP to monitor the Ceasefire line and report the ceasefire violations to United Nations Security Council as a peacekeeping mission. After the conversion of CFL into LoC, India claimed that now CFL has been abolished and a new understanding has been made between Indiaand Pakistan, so 
there is no need of UNMOGIP now. India has not allowed UNMOGIP to visit LoC after Shimla Agreement but even then the mission of UNMOGP is present in Delhi and Srinagar. However, Pakistan responded that UNMOGIP will continue to monitor the LoC and will report the violations of ceasefire line to United Nations Security Council (UNSC) as per the spirit of the resolutions of the UNSC. The United Nations Security Council (UNSC) did accept the claim of India and adopted a new resolution and directed the UNMOGIP to continue the monitoring of LoC and reporting of the ceasefire line. ${ }^{11}$

b) The armed forces of India and Pakistan were withdrawn to their respective sides of the International border. However, this principle was not applied on the LoC as the word "International border" has been expressly mentioned in the agreement.

c) All the Pakistani POWS were also returned back to Pakistan.

\section{UN Resolutions on Jammu and Kashmir: Nature and Mandate}

There are around twenty resolutions of the United Nations Security Council (UNSC) and United Nations Commission on India and Pakistan (UNCIP) on Jammu and Kashmir and these resolutions recognizes Jammu and Kashmir as the disputed territory and also recognizes the right to self-determination of the people of Jammu and Kashmir.

These resolutions were adopted by the United Nations Security Council (UNSC) under Chapter VI of the Charter of the United Nations. Moreover, there are also two very important resolutions of the United Nations Commission for India and Pakistan (UNCIP) which was a very important commission established by the United Nations Security Council (UNSC) to mediate the conflict of Jammu and Kashmir. ${ }^{12}$

The United Nations played an important role in trying to mediate the conflict of Jammu and Kashmir peacefully through active mediation and conciliation. India took the issue to United Nations Security Council under Article 35 of the Charter of the United Nations ${ }^{13}$ on January 01, 1948 and then Pakistan submitted her reply in the UNSC 
on January 15,1948 . On the receipt of written documents by both India and Pakistan, United Nations Security Council passed the first resolution of 38 and requested both India and Pakistan to refrain from further aggravating and deteriorating the situation in Jammu and Kashmir. On January 20, 1948, UNSC established a three member's commission to investigate the fats and assist the UNSC to resolve the conflict of Jammu and Kashmir. This three member's commission was converted into five members' commission on April 21,1948 by UNSC through resolution No 47. The commission was directed by the UNSC to go to the subcontinent and restore peace in the region and also prepare for the plebiscite to decide the conflict of Jammu and Kashmir. ${ }^{14}$

This resolution also directed the commission to follow the three step process for the restoration of peace. This commission was called as United Nations Commission for India and Pakistan (UNSCIP) and then to evolve a mechanism for the resolution of the conflict of Jammu and Kashmir, UNCIP also passed two resolutions. The first resolution of UNCIP was passed on August 13, 1948 and second resolution of the UNCIP was passed on January 05, 1948. These two resolutions are very important and are considered as agreements between India and Pakistan as both the states partially enforced these resolutions and also signed these two resolutions like agreements. The former resolution of UNCIP negotiated the ceasefire agreement between India and Pakistan and also established a ceasefire line across the erstwhile state of Jammu and Kashmir which divided the erstwhile state of Jammu and Kashmir into Pakistan administered Jammu and Kashmir and Indian administered Jammu and Kashmir. The second resolution of UNCIP recognized the right to self-determination of the people of Jammu and Kashmir. Then another resolution No 51 was passed by UNSC on June 03,1948 to ask the UNCIP to visit the area of the Jammu and Kashmir for discharging its duties effectively. The UNSC adopted another resolution No $80^{15}$ on March 14, 1950 and appreciated India and Pakistan for ceasefire agreement and also urge both the states for expediting the demilitarization process. This resolution also confirmed the appointment of Fleet admiral Chester W. Nimitz as the plebiscite administrator. 
The UNSC adopted another resolution No $91^{16}$ on March 30, 1951 to recognizing a report submitted by Sir Owen Dixen, who was the United Nations Representative for India and Pakistan, to highlight the main differences between India and Pakistan for holding the promised and agreed plebiscite in the Jammu and Kashmir. Another resolution No 96 was adopted by the UNSC on November 10, 1951 to urge both India and Pakistan to continue their efforts for peaceful settlement of Jammu and Kashmir. On December 23, 1952, UNSC adopted a very important resolution No 98 on the demilitarization plan and specific number of troops to be kept in Jammu and Kashmir by India and Pakistan respectively.

In 1957, three resolutions were passed by UNSC on Jammu and Kashmir. These were resolutions No 122, 123 and 126. The resolution No 122 was very important as it declared specifically that the assembly proposed by the Jammu and Kashmir National conference could not propose any solution to the conflict of Jammu and Kashmir and the conflict of Jammu and Kashmir can only be resolved through UN supervised plebiscite. The UN mediation on Jammu and Kashmir remained active and effective from 1948 to 1957. From 1957 to 1971 , seven resolutions were adopted by the UNSC related to Jammu and Kashmir but all these seven resolutions were related to the ceasefire violations and urge to both India and Pakistan to observe ceasefire violations on ceasefire line. ${ }^{17}$

In 1965, UNSC adopted five resolutions No 209, 210,211,214 and 215 . These resolutions were mostly related to the ceasefire line and maintaining peace and order around ceasefire line. Last two specific resolutions on Jammu and Kashmir were adopted by UNSC in 1971 but those were also mostly related to ceasefire line and its observing ceasefire agreement by both India and Pakistan. These were resolutions No 303 and 307. These eighteen resolutions of UNSC and two resolutions of UNCIP are the most important documents on the conflict of Jammu and Kashmir and the legal aspect of Jammu and Kashmir is mostly based on these twenty resolutions adopted by UNSC and UNCIP. 


\section{Are Resolutions of UNSC Binding?}

This is most debated question nowadays and I often observe people giving their legal and political arguments to prove their points of views. Generally, people think that there are two kinds of resolutions adopted by United Nations Security Council (UNSC). First kind of resolutions are those which are adopted by the UNSC under Chapter VI of the Charter of the United Nations and second kind of resolutions are adopted by the UNSC under chapter VI of the Charter of the United Nations. So a common and popular argument is that resolutions passed under Chapter VI are non-binding in nature and those passed under chapter VI are binding. As resolutions of the UNSC on Jammu and Kashmir were adopted under article 35 of the Charter of United Nations which falls in Chapter VI, so all the resolutions of the UNSC and UNCIP are non-binding in nature and cannot be applied in Jammu and Kashmir. Moreover, these scholars also think that Shimla Agreement is a valid bilateral treaty between India and Pakistan being ratified by their parliaments and later in time then all the eighteen resolutions of the UNSC and UNCIP will have an overriding effect on all the twenty resolutions of the UNSC and UNCIP. Both of these claims are baseless, against the spirit of International law, opposite to the principles and provisions of the Charter of the UN and in violation of the relevant decisions of the International Court of Justice (ICJ). ${ }^{18}$

First of all, we can discuss the binding nature of the resolutions of the UNSC on Jammu and Kashmir. There are many legal arguments which can easily prove that the resolutions adopted by UNSC on Jammu and Kashmir under chapter VI of the Charter of the United Nations are binding and are still applicable on the longstanding conflict of Jammu and Kashmir. Following are few legal arguments, inert alia:

a) In early years of UNSC, there was no practice of mentioning the chapter number with the resolution adopted by the UNSC and all the resolutions adopted by the UNSC were considered binding and valid. As India took the conflict of Jammu and Kashmir to UNSC under Article 35 and Pakistan also invoked same article while submitting its reply, so we came to know that these resolutions are passed under chapter 
VI. So on the basis of the practice of the UNSC in its initial years of the establishment, all the resolutions of the UNSC and UNCIP are binding in nature and applicable on the conflict of Jammu and Kashmir in its true letter and spirit.

b) The case of the binding nature of the resolutions of the UN Charter ${ }^{19}$ came before the World court in famous, "Namibia Advisory Opinion" 20 , in which the court held that all the resolutions of the UNSC are binding in nature as per article 25 of the UN charter without any difference of chapter VI or chapter VII. The Article 25 imposes upon the UN members the obligations to accept and carry out the decisions of the Security Council.

The court held that the article 25 of the UN Charter is not placed in Chapter VII but in that part of the UN Charter which deals with the functions and powers of the UNSC. Hence, Article 25 of the UN Charter is applicable on all the resolutions of the UNSC whether adopted under chapter VI or chapter VII and all these resolutions are binding in nature. This also proves that the resolutions of the UNSC and UNCIP on the Jammu and Kashmir are binding in nature and applicable on the conflict of Jammu and Kashmir.

c) The question of the binding nature of the UN Resolutions was also discussed and resolved by the delegates of the India and Pakistan during Security Council debate in the $761^{\text {st }}$ meeting of the council. In this meeting, the Pakistani delegate requested the Indian delegate to explain the obligations of the parties under the terms of the International agreement for a plebiscite under UN Resolutions. In reply to this, the Indian delegate responded that India is only bound by those international engagements on Jammu and Kashmir which it had voluntarily accepted in the resolutions of 13 August 1948 and 05 January 05, 1949. Hence these two resolutions of the UNCIP were voluntarily accepted by both India and Pakistan and are just like international agreements. This proves that resolutions of UN on Jammu and Kashmir are binding and valid. ${ }^{21}$ 


\section{Relationship between Bilateral Agreement and resolution of UNSC: Principles of International Law}

There is also a debate and claim by few scholars, mostly from India, that the Shimla Agreement has invalidated all the twenty resolutions of the UNSC and UNCIP. They also have the opinion that the invalidation of the resolutions of USNC and UNCIP on Jammu and Kashmir is the legal impact of the Shimla Agreement and now onward, the conflict of Jammu and Kashmir can only be resolved through bilateral negotiations in a peaceful manner and Pakistan cannot internationalize the Kashmir issue or cannot seek third party mediation in the light of the provisions and agreements made between India and Pakistan in the Shimla Agreement.

There are few very important questions in this regard which needs legal and logical analysis to clarify the misconceptions and planned propaganda on the validity and applicability of the resolutions of the UNSC and UNCIP on Jammu and Kashmir. These significant questions are as follows: What is the legal impact of the Shimla Agreement on the UN resolutions on Jammu and Kashmir? How and to what extent the Shimla Agreement has invalidated the applicability and relevancy of the UN Resolutions on Jammu and Kashmir? What is the status and relevancy of the UN Resolutions on Jammu and Kashmir in post Shimla Agreement scenario?

How the UN Resolutions on Jammu and Kashmir can be interpreted in the light of the provisions of the Shimla Agreement? What is the status of the UN Resolutions on Jammu and Kashmir in the backdrop of the general principle that "later treaty abrogates the earlier one"?

The main debate is around the use of bilateral approach versus international or multilateral approach for the resolution of the conflict of Jammu and Kashmir. The provisions of the Shimla Agreement, 1972 states that both the states will resolve all the bilateral issues peacefully through bilateral negotiations or through any other peaceful means as mutually agreed between both the states. On the other hand, the UN Resolutions on Jammu and Kashmir recognizes the right to self-determination ${ }^{22}$. This shows a stark difference in the modus operan di as envisaged and proposed 
by both the legal frameworks under International law. The Shimla Agreement proposed bilateral approach and UN Resolutions on Jammu and Kashmir proposed internationalized and multilateral approach under International law to resolve the conflict of Jammu and Kashmir under International law. ${ }^{23}$

The careful analysis and perusal of the provisions of the Shimla Agreement regarding the impact of the Shimla Agreement on the resolutions of the UNSC on Jammu and Kashmir states as under:

a) The paragraph (i) of the UN Charter ${ }^{24}$ specifically highlight that the principles and purposes of the UN Charter will govern the relationships between India and Pakistan. This clause is very important and have far reaching legal effect under International law. If we analyze the purposes of the UN Charter, then we came to the purpose of the UN Charter as mentioned in the Article 1 and paragraph II of the UN Charter. This paragraph highlights the purpose of the UN Charter as follows, "To develop friendly relations among nations based on respect for the principles of equal rights and self-determination of peoples."

This shows that the right to self-determination ${ }^{25}$ which has been recognized by the UN resolutions on Jammu and Kashmir is also one of the important and salient purposes of the UN charter and is still the governing principle between the relationships of India and Pakistan. ${ }^{26}$

b) Article 103 of the UN Charter gives a very cardinal and leading principle to regulate the legal relationships between the Shimla Agreement and the UN resolutions on Jammu and Kashmir. This principle is "lex prior derogat posterior" which means the later treaty shall be invalid if incompatible with the earlier treaty. This principle is against another very important and cardinal principle of International law which is, "ex posterior derogate priori" which means that the later treaty invalidates the earlier one. The Indian scholars present the second principle as a legal argument to prove that the Shimla Agreement being the later in time has invalidated all the International agreements made between India and Pakistan on the two resolutions of the UNCIP; August 13, 
1948 and January 05,1949 . According to this article No 103, there are two kinds of obligations. First set of obligations are those which are undertaken by the members through UN Charter. For example, the obligations rises out of the resolutions of the UNSC and UNCIP are the obligations undertaken by the members through the charter of UN. On the other hand, the other set of obligations are the obligations arises out of the international agreements.

So the obligations undertaken by the members through any bilateral or other treaties are the obligations under International agreements. The Article 103 of UN Charter says that obligations created by UN Charter shall prevail upon the obligations created by the International agreements. Hence, the obligations of India and Pakistan under UN Resolutions shall prevail on the obligations of both the states undertaken through the Shimla Agreement. ${ }^{27}$

So as per article 103 of UN Charter, the principle of "lex prior derogat posteriori" will be applicable on the comparison between the Shimla Agreement and UN Resolutions on Jammu and Kashmir as the obligations arising out from both the legal documents are incompatible. This article aims to regulate such kinds of incompatibility between different legal obligations under International law. Moreover, the principle of "ex posterior derogate priori" will be applicable only where there are two different bilateral or multilateral treaties and having same nature of legal obligations undertaken by the signatory states of the treaties.

c) In international law there is a concept of Jus Cogens under article 53 of the Vienna Convention of the Law of Treaties which states as follows, "a treaty is void if at the time of its conclusion, it conflicts with the preemptory norm of general International law."

Under international law, Principle of Self-determination is a Jus Cogens and the provisions of the Shimla Agreement cannot be interpreted to exclude or invalidate the UN Resolutions on Jammu and Kashmir as these resolutions provide the right to self-determination under International law which has the legal status of Jus Cogens. Hence, it is not legally possible to give the opinion that Shimla Agreement 
has invalidated the Principle of Self-determination which is a Jus Cogens as recognized under International law and also recognized and provided by UNSC for people of Jammu and Kashmir through its resolutions on Jammu and Kashmir. ${ }^{28}$

d) There is another strong argument that resolutions of the UNSC and UNCIP are still valid and applicable on the conflict of Jammu and Kashmir. The existing Line of Control (LoC) was Ceasefire Line (CFL) which was agreed between India and Pakistan in the Karachi Agreement, entered into between India and Pakistan on July 27, 1949 in accordance and with the mandate of the resolutions of the UNSC and UNCIP.

In order to monitor the CFL (LoC) and regularly report the violations of the ceasefire line, UNSC established United Nations Military Observers Group for India and Pakistan (UNMOGIP) in 1951. On 30 March 1951, following the termination of the United Nations Commission for India and Pakistan, through Resolution 91, the Security Council established a United Nations Military Observer Group, which mandated military observers to conduct field tasks such as reconnaissance field trips, facilitating observation posts along the Line of Control. Under the Karachi Agreement of 1949, the Observer Group was also supposed to conduct investigations into the complaints of alleged ceasefire line violations submitted by either India or Pakistan.

Further, the Observer Group was to submit a summary of its findings to both India and Pakistan and to the Secretary General of the United Nations. This UNMOGIP has been still present on both sides of LoC and also in Delhi and Islamabad and has been regularly monitoring and reporting to UNSC from Pakistani side of LoC. Recently, two closed door meetings of UNSC were arranged on the request of China and in both of those two meetings, discussions were made on the regular reports submitted by the UNMOGIP to the UNSC. The presence and working of the UNMOGIP is another argument to prove that the resolutions of the UNSC and UNCIP are still valid and operative under International law and there is no adverse legal impact of the Shimla 
Agreement on the applicability of the resolutions of the UNSC and UNCIP on Jammu and Kashmir.

\section{Conclusion}

The detailed analysis and careful review of both Shimla Agreement and the resolutions of the UNSC and UNCIP on Jammu and Kashmir reveals that there is no adverse legal impact of the Shimla Agreement on the applicability and validity of the said resolutions. Although there has been a active stage of UN mediation on the conflict of Jammu and Kashmir from 1948 to 1957 and then a less active stage of UN Involvement on conflict of Jammu and Kashmir from 1957 to 1971, but that does not have any legal impact on the resolutions of the UN on Jammu and Kashmir. Moreover, it has also been observed that there has been rare resolutions of the UNSC on Jammu and Kashmir after Shimla Agreement and India and Pakistan also entered into many rounds of bilateral negotiations and agreements of mutual interests, but the applic ability and scope of the resolutions of the UN on Jammu and Kashmir is still there and one good example of the relevancy of the UN resolutions on Jammu and Kashmir were the two closed door meetings of the UNSC on the situation of Jammu and Kashmir on the reports submitted by UNMOGIP in post August 05, 2019 scenario.

As Shimla Agreement recognizes all the principles and purposes of the UN Charter, so it means it also recognizes the principle of Selfdetermination as recognized by UNSC for people of Jammu and Kashmir through around twenty resolutions under International law. Moreover, being Jus Cogens, right to self-determination is the basic, fundamental and inalienable right of all the human beings without any discrimination so there cannot be any adverse effect of the Shimla Agreement on the said resolutions. Finally, the principle of "lex prior derogat posteriori" also determines the validity, relevancy and applicability of all the resolutions of the UN on Jammu and Kashmir. The Shimla Agreement has its own nature, application and scope and it does not have any direct or indirect adverse legal implications on the mandate of the UNSC under all the resolutions of UN on Jammu and Kashmir whereby it is the legal responsibility of the United Nations to resolve the conflict of Jammu and Kashmir as per UN resolutions. 


\section{References}

1 Africa, S. and T.D. R. of C. (1999). Peace Agreements Digital

Collection. Foreign Affairs, (January), 6-7.

2 Ibid

3 Ganguly, R.(1998). India, Pakistan and the Ka shmir Dispute. Assembly, 112. Retrieved from https://core.ac.uk/download/pdf/4 1338433.pdf

4 Qadeer, M. A. (2018). United Nations Resolutions on Ka shmir and Their Relevance. Journal of Strategic Affairs, 2(2), 81.

5 Rizvi, H. (2013). Simla Pact: The great success for Pakistan. Pakistan Vision, 14(4), 63-75. Retrieved from

http://pu.edu.pk/images/journal/studies/PDF-FILES/Artical4_Vol_14_No1.pdf

6 Ibid

7 Government, T., \& Nations, U. (1972). Agreementon Bilateral Relations between the Government of India and the Government of Pakistan (Simla Agreement),(July), 3. Retrieved from

https://peacemaker.un.org/sites/peacemaker.un.org/files/IN PK_720702_Simla Agreement.pdf

$8 \quad$ Ibid

9 The India-Pakistan Simla a greement, 3 July 1972.(1972). Survival, 14(5), $242-242$.

10 Ibid https://doi.org/10.1080/00396337208441358

11 Source : Pakistan Horizon, Third Quarter, 1972, Vol. 25, No . 3 , THE SIMLA ACCORD( Third Quarter, 1972), pp . 111-156Published by : Pakistan Institute of International Affairs Stable URL : https://www.jstor.org/stable/41403851.(1972), 25(3), 111-156.

12 Cheema, P.I., \& Iqbal Cheema, P. (2016). Resolving kashmir dispute a nalyzing va rious approaches. Margalla Papers, 20(1), 23-36. Retrieved from http://www.ndu.edu.pk/issra/issra pub/articles/margalla pa per/Margalla-Papers-2016/2_Dr_Pervaiz_Iqbal_Cheema.pdf

13 UN. Charter of the United Nations a nd Statute of Justice (1945).

14 Cheema, P.I.(2014). The Ka shmir Dispute: Key to South Asian Peace, 120.

15 Qadeer, M. A. (2018). United Nations Resolutions on Ka shmir and Their Relevance. Journal of Strategic Affairs, 2(2), 81.

16 Ibid

17 Ibid

18 Qadeer, M. A. (2018). United Nations Resolutions on Ka shmir a nd Their Relevance. Journal of Strategic Affairs, 2(2), 81.

19 UN. Charter of the United Nations a nd Statute of Justice (1945). 
20 Advisory Opinion. (21 June 1971).Reports of Judgments, Advisory Opinions and Orders. International court of Justice.

21 Hussain, I. (1998). Ka shmir Dispute: An International Law Perspective. Isla mabad: National Institute of Pakistan Studies.

22 Bursac, S. (2010). The right of peoples to self-determination. Medjunarodni Problemi, 62(2), 276-313.https://doi.org/10.2298/medjp1002276b

23 Cheema, P. I. (2014). The Kashmir Dispute: Key to South Asian Peace, 120.

24 UN. Charter of the United Nations a nd Statute of Justice (1945).

25 Bursac, S. (2010). The right of peoples to self-determination. Medjunarodni Problemi, 62(2), 276-313.

26 Hussain, I. (1998). Ka shmir Dispute: An International Law Perspective. Islamabad: National Institute of Pakistan Studies.

27 Cheema, P. I. (2014). The Kashmir Dispute: Key to South Asian Peace, 120.

28 Hussain, I. (1998). Kashmir Dispute: An International Law Perspective. Islamabad: National Institute of Pakistan Studies. 